Historic, Archive Document

Do not assume content reflects current scientific knowledge, policies, or practices. 



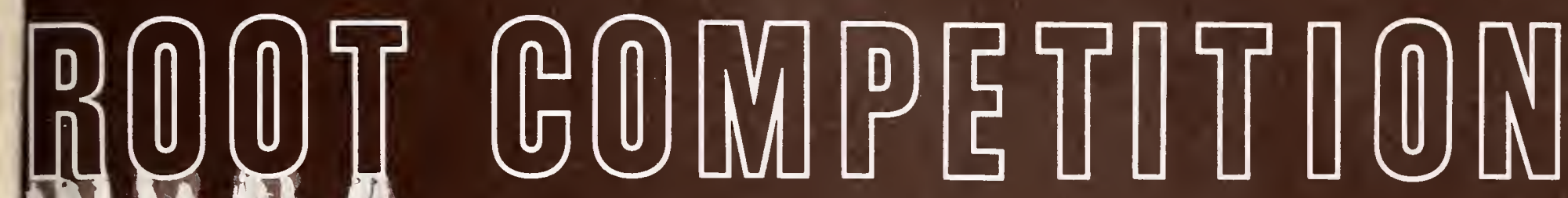

EETVNEEN

PONDEROSA PINE GE=DLINCS

AND GRASS

M.M. LARSON

GILBERT H. SCHUBERT

USDA FOREST SERVICE

Research Paper RM-54

ROCKY MOUNTAIN FOREST AND RANGE EXPERIMENT STATION

FOREST SERVICE U.S. DEPARTMENT OF AGRICULTURE 

USDA Forest Service

Research Paper RM-54

Root Competition Between Ponderosa Pine Seedlings and Grass

by

M. M. Larson, Forest Physiologist

and

Gilbert H. Schubert, Principal Silviculturist

Rocky Mountain Forest and Range Experiment Station ${ }^{1}$

${ }^{1}$ Central headquarters maintained at Fort Collins, in cooperation with Colorado State University; authors are located at Flagstaff, in cooperation with Northern Arizona University. Larson is now with the Forestry Department, Ohio Agricultural Research and Development Center, Wooster, Ohio. 


\section{CONTENTS}

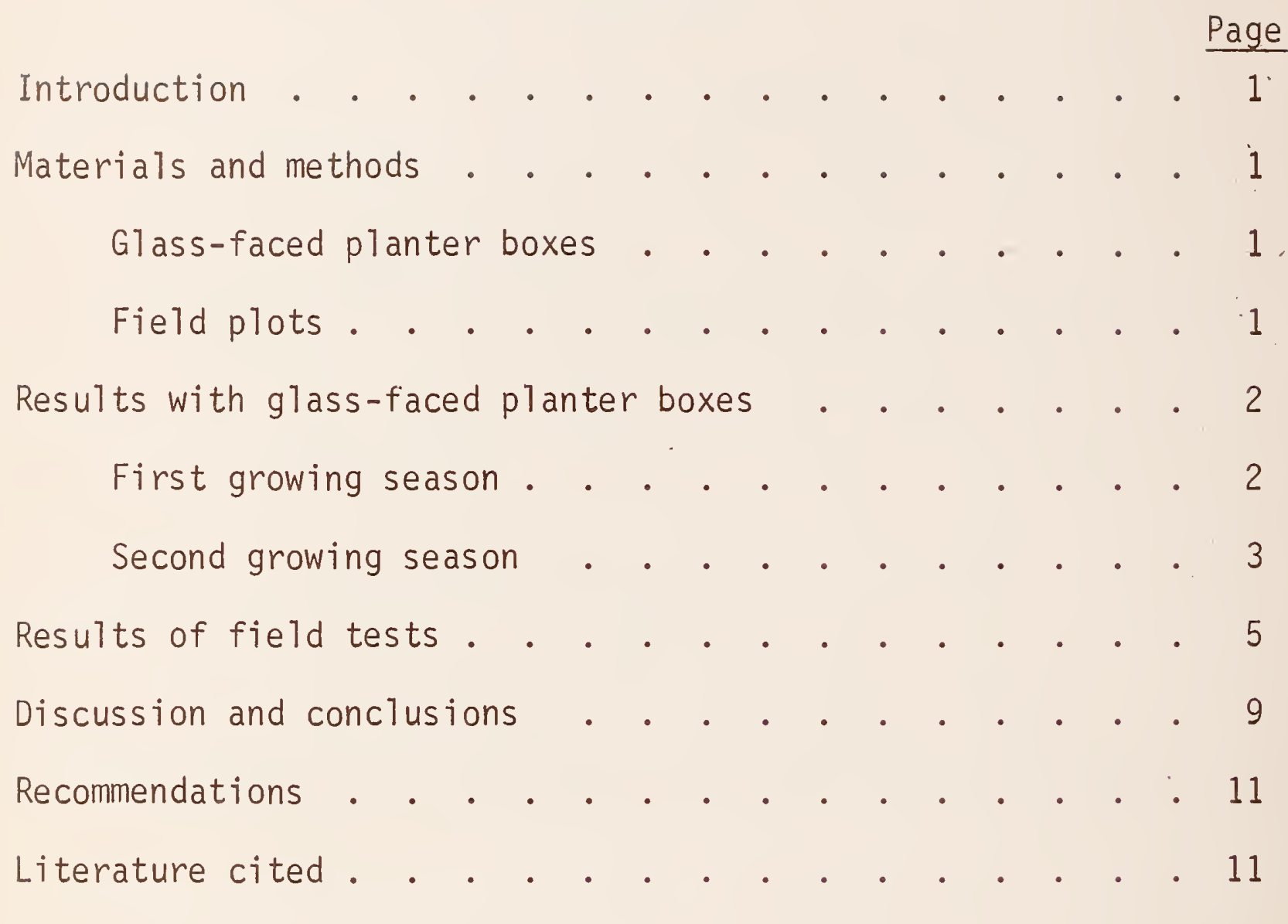




\title{
Root Competition Between Ponderosa Pine Seedlings and Grass
}

\author{
M. M. Larson and Gilbert H. Schubert
}

\section{Introduction}

Grass is a common ground cover throughout the ponderosa pine (Pinus ponderosa Laws.) forests of the Southwest. Although a valuable forage resource, its presence is definitely detrimental to initial establishment of coniferous reproduction. Certain grasses, however, seem to compete less intensely than others with pine seedlings. This difference in competitiveness is exemplified by two native bunchgrasses: Arizona fescue (Festuca arizonica Vasey), a strong competitor, and mountain muhly (Muhlenbergia montana (Nutt.) Hitchc.), a mild competitor (Pearson 1942). This Paper reports on investigations of the treegrass relationship on the Fort Valley Experimental Forest near Flagstaff, Arizona.

\section{Materials and Methods}

The study was conducted in two environments: glass-faced planter boxes set in the ground at the Fort Valley nursery, and field plots in a nearby old clearcut opening in a ponderosa pine stand. Both locations were at an elevation of about 7,400 feet.

\section{Glass-Faced Planter Boxes}

Dormant ponderosa pine, Arizona fescue, and mountain muhly seedlings were planted on April 12, 1963, in nine glassfaced boxes previously described by Larson (1962) and Lavin (1961) to study root development. These boxes, 2 feet by 3 inches at the top and 2 feet deep, were slid into wooden frames that had been buried in the ground at a $30^{\circ}$ angle from vertical. The side of the box with the removable glass face was placed downward and the top level with the soil surface.

Moist, gravelly, clay loam soil, derived from basalt, was dug from a nearby pit and transferred to the boxes at approximately the same original horizons. Adequate drainage was provided through a layer of coarse volcanic cinders and holes drilled in the bottom of the boxes. After each box was filled with soil it was lifted from the wooden frame, placed flat on the ground, and the glass plate removed.

Seedlings were then placed on the exposed soil at regular planting depth with roots extended. Two 2-0 ponderosa pines from the adjacent nursery beds were planted 1 foot apart in each of the nine boxes. Arizona fescue and mountain muhly plants from a nearby natural grass stand were separated into very small individual entities, root pruned to 4 inches, and then planted in six of the boxes, three for each of the two grass species. Three grass transplants were planted on each side of the pine. The glass was then replaced carefully to avoid disturbing the roots and the box inserted into the frame.

The plants were watered immediately after planting and at weekly intervals during the spring and fall drought periods. Each watering was equivalent to 0.5 inch of rain.

Roots were measured twice weekly during the spring of the first growing season. The interval between subsequent measurements was adjusted according to the amount of new root growth. Heights were measured several times during the growing season.

Final measurements were made at the end of two full growing seasons. After the depth of the pine root system was measured, the pine and grass seedlings were carefully washed from the soil. New root tips on the pines were counted, then all plants were photographed, dried, and weighed.

\section{Field Plots}

Two-year-old ponderosa pine seedlings were planted April $25-28,1964$, in six replications each containing six plots - two each of Arizona fescue, mountain muhly, and denuded cover types. Nine pine seedlings, of Arizona seed origin grown at the Bend Nursery in Oregon, were planted at a 1 -foot spacing in each of the 3-foot-square plots.

The natural grass stand in the study area consisted almost entirely of the two bunchgrass species arranged as a mosaic of single species clumps up to 6 feet in diameter. Plots were located in the centers of the grass clumps and denuded spots. All six plots of each replication were within a 25 -foot-square area.

\section{Figure 1.--Mountain mully cover type plot planted with nine 2-0 ponderosa pine seedlings, one to each square foot. The black border is the upper edge of the plastic root barrier. White tags indi- cate the location of some pine seedlings.}

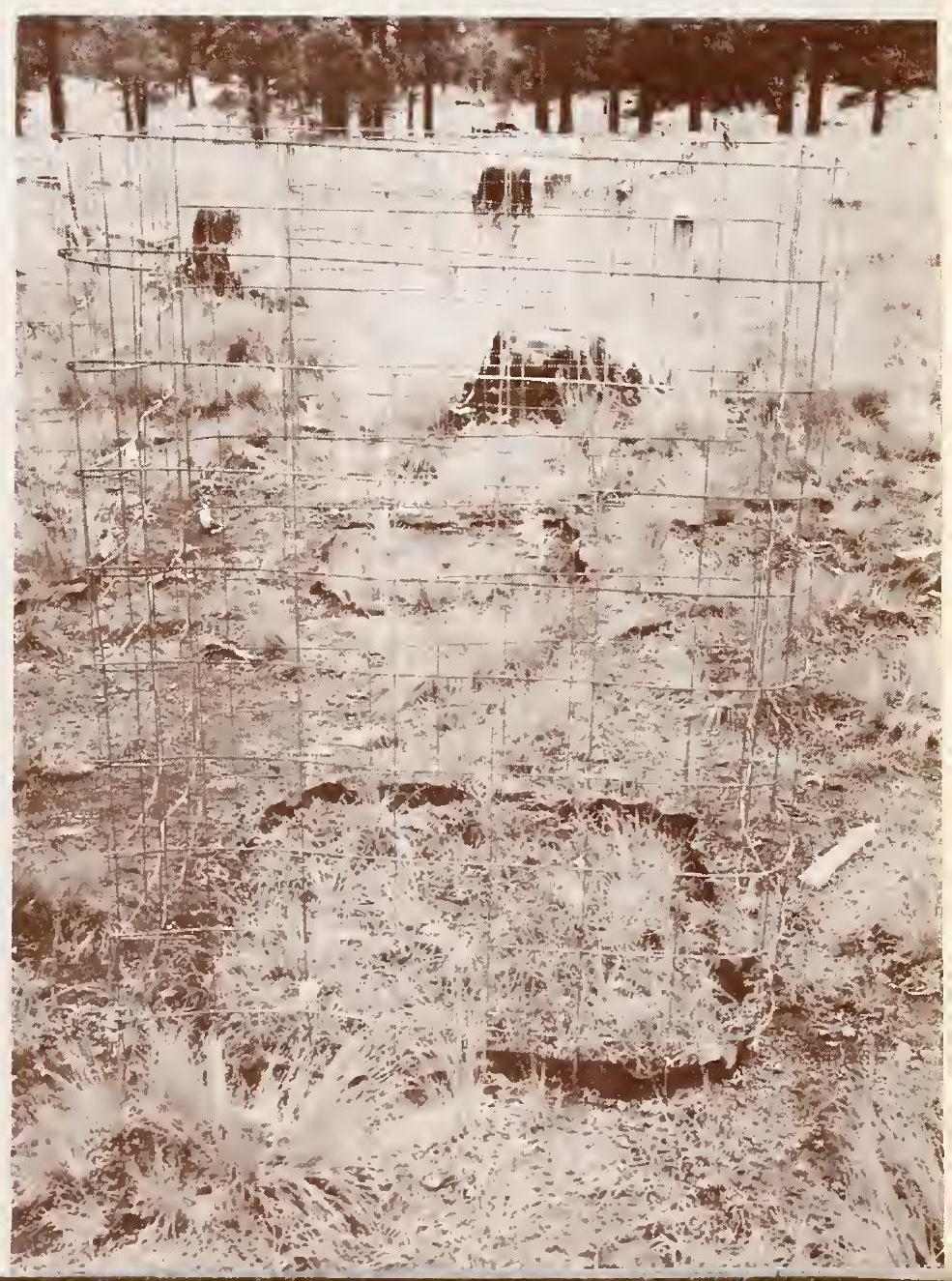


Eoch 3-foot-square plot was surrounded by a rootmoisture borrier of 6-mil black plastic film to a depth of 20 inches and a 5-foot woven wire fence to exclude browsing animols (fig. 1). Gross immediately odjacent to the plonted pines was repeatedly clipped to 2 inches so that all trees could receive direct sunlight during the noon hours. One rondomly selected plot of each cover type in each replication wos watered during the drought periods to reduce competition between plonts for moisture.

Soil moisture and temperature in the plots were measured with electrical resistance blocks ond thermistors, respectively. All moisture ond temperoture units were colibroted in the loboratory with soil from several depths within the study area. Thermistors were installed in holf the plots to meosure soi! temperature. Two soil moisture units were ploced ot the 4 -inch depth in all unwatered plots and in watered plots of replications 2 and 6 . These units were spaced 1 foot apart and 1 foot from the moisture barrier. In addition, two soil moisture units were placed of $8-, 16-$, ond 24 -inch depths in the unwotered plots of replications 1 and 5 . The moisture units and thermistors were read ot about middoy.

Air temperature, relative humidity, and precipitation were measured at the center of the study area. The recording hygrothermogroph, set in a wooden shelter open on two sides, meosured air temperature ond relative humidity of 3 inches above the ground surfoce.

Water balance of pine seedlings was determined four times during the first growing season. One needle fascicle was detached from each seedling about 10 hours ofter sunrise, enclosed in clear plastic wrap, and taken to the laboratory. It wos found thot needles so treoted could be stored at room temperatures for up to 18 hours without significant loss of green weight or capacity to resaturate. Needle moisture content (NMC) and water saturotion deficit (WSD) were determined by the method described by Harms ond McGregor (1962).

The center pine seedling in each plot was excovoted on July 14 of the first growing season to determine new root growth. The remoining seedlings were excovoted in October 1965 two full growing seosons after planting. Data recorded for each seedling were (1) total root depth, (2) length of laterol roots, (3) number of new root tips, (4) total height, ond (5) dry weight of tops ond roots.

\section{Results with Glass-Faced Planter Boxes}

\section{First Growing Season}

Fescue roots started growth about 2 weeks earlier than muhly or pine roots. The first new fescue roots oppeored on April 26, about 2 weeks ofter planting. Muhly ond pine developed new root tips on May 12. By the end of Moy all gross plonts and 72 percent of the pines had new root growth. The remaining pines storted their root growth in June, about 2 months after plonting.

The origin of new root growth differed between the pines ond grasses. The pines, plonted to on average depth of 10 inches, hod new roots develop about 2 inches from the ends. The grosses, planted to on average depth of 4 inches, hod new roots develop at the ends of the pruned tips.

Grass roots reoched the bottom of the 2 -foot-deep boxes before the pines. By June 28, 52 fescue and 13 muhly roots penetrated to the bottom of the six boxes containing gross. Roots of 11 pines grew to the bottom of the boxes in July, two more in August, and one in September. Roots of the remaining four pines did not grow to the 2-foot depth the first yeor.

Growth rotes for both pine and grass roots were highest in lote May and early June (figs. 2, 3). During this period, growth rotes of the five fostest growing roots of eoch species averaged 2.5 inches per week for pine, 3.7 inches for fescue, ond 3.8 inches for muhly. Growth rotes of pine roots were similar for the three cover types.

The root growth pattern of the pines differed from that of the grosses. Pine roots generally grew downward at oblique ongles or horizontally 0 few inches and then downword. All grass roots grew nearly straight down. Since total new root growth was meosured, the growth measurements for pines do not indicate root depth with respect to ground surface (fig. 2), whereos growth for the grass roots does reflect root depth (fig. 3).

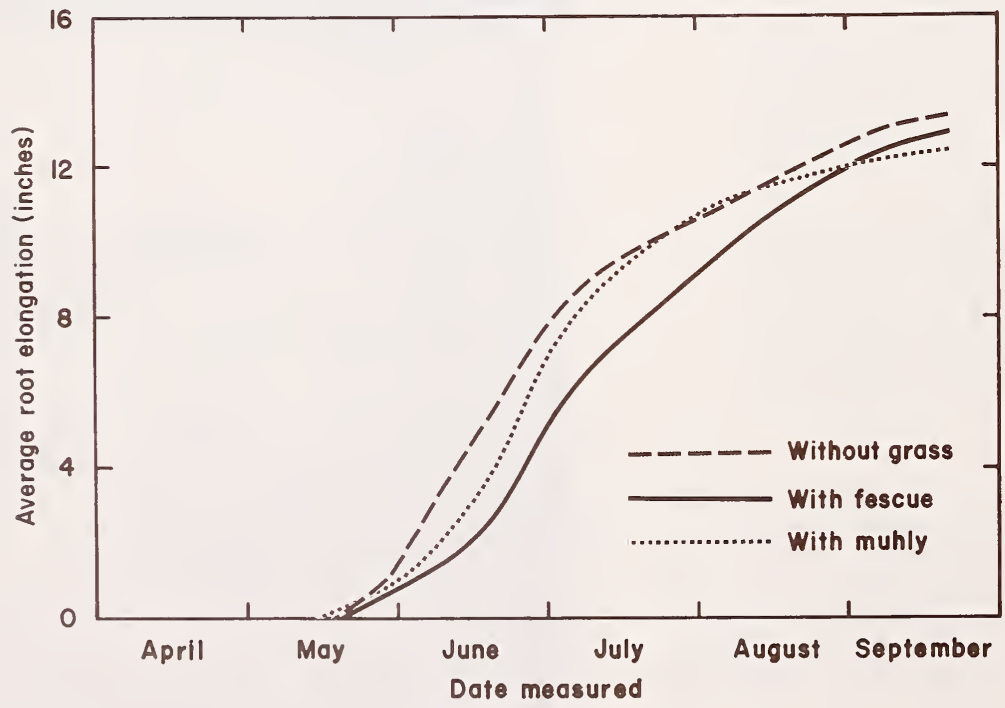

Figure 2.-Average pondercsa pine root elongation in glass-faced planter boxes with Arizona fescue, mountain muhly, and without grass. 
Figure 3.--

Comparison of

root elongation

of Arizona fescue, mountain mukly, and ponderosa pine in glass-faceá planter koxes.

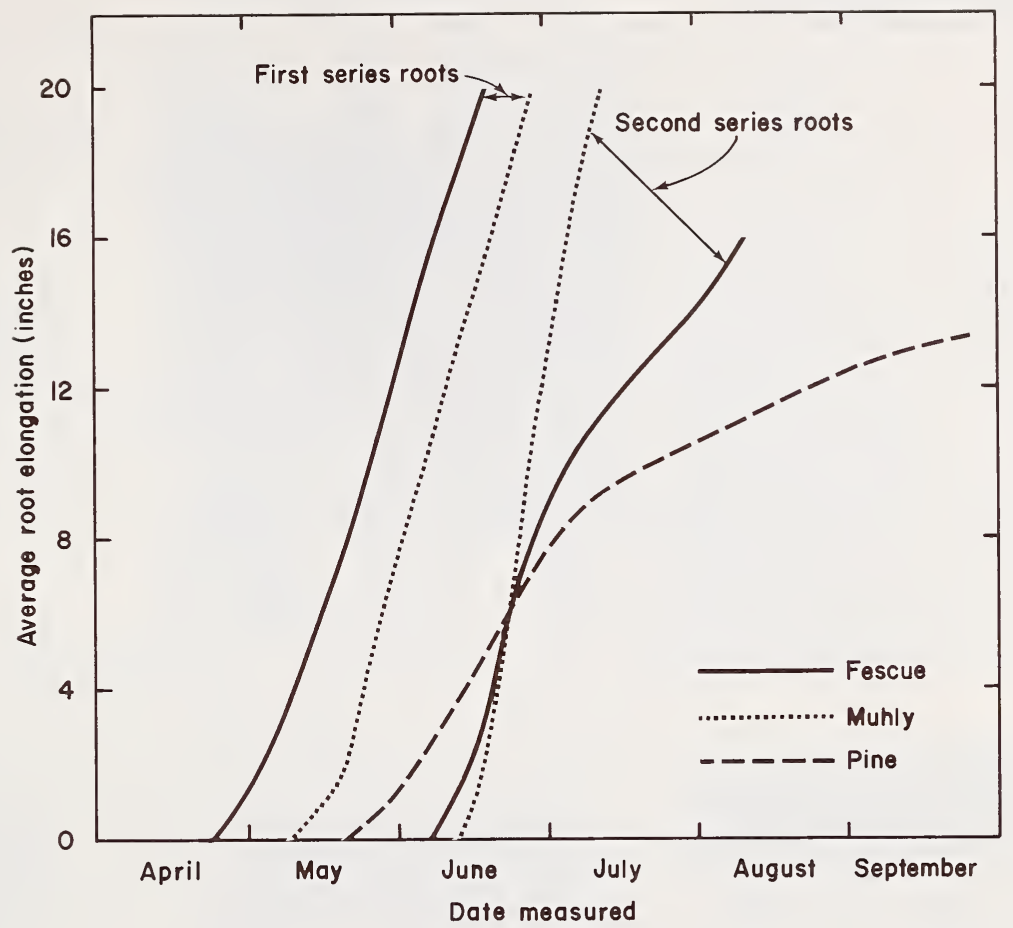

Some gross roots grew in direct contoct with older pine roots. Growth rotes did not chonge before or ofter contoct with the pine root.

Both gross species produced several series or "flushes" of new moin roots. All new sets of "sinker" roots originoted neor the same point os the first series. The second series of roots wos initiated in mid-June. The third series storted in lote July ond early August. Fescue plonts produced a fourth series in September.

Second series roots grew ot obout the some rote os first series (fig. 3). These roots averoged obout 3.5 inches per week except for two second series muhly roots, which grew 5 inches per week. Third ond fourth series roots grew very slowly.

All second ond higher series gross roots were chorocteristicolly "woolly" due to their white color ond obundonce of root hoirs. These roots olso were lorger in diometer thon first-order roots. By mid-July the glass-foced surface wos covered with gross roots, which obscured the growth of older roots. This dense mot of gross roots ropidly dried out the soil adjocent to the glass during drought periods, even though the plonts were wotered weekly.

None of the pine terminol buds elongated after plonting. However, new buds formed within needle foscicles during midsummer. These new buds grew less thon 1 inch during the remoinder of the growing seoson.

\section{Second Growing Season}

Pine root growth differed from thot of gross roots during the second seoson olso. Roots of pine seedlings plonted with gross grew very little the second yeor. None hod new white tips neor the bottom of the boxes. In controst, pines in boxes without gross developed two to eight thick, white-tipped roots neor the bottom by mid-Moy, ond several new, smoller loterols of the 14 to 18 -inch depth by late May. All roots ceased growth during the June drought.

Fescue roots were ogoin the first to begin growth the second yeor. New main roots were evident by mid-April. A slowgrowing second series storted in lote Moy, followed by o fast growing third series in lote July ofter the summer roins storted.

First new muhly roots oppeored in mid-Moy, obout a month loter thon the fescue ond obout the some time os the pines in gross-free boxes. Muhly produced o second series root system in lote June, but no third series the second yeor.

Along with the new moin root system, both grosses hod mony smoll high-order loterols develop on the previous yeor's moin root system. Thirty such smoll roots were counted on fescue plonts in one of the boxes in lote April.

Roots of the three species were eosily identified. Pine roots were lorgest in diometer ond turned dork brown. Fescue roots chonged to dork groy-brown with oge, while muhly roots retoined their light ton color throughout the 2-year study.

Top growth also differed for the two grosses. Fescue completed its top growth by June 19, when muhly hod completed only 63 percent of its growth. By early July, muhly plants hod surpossed fescue ond averoged 4 inches toller in October (toble 1).

When excovoted in October, muhly roots oppeored to be dormont, whereos mony fescue roots still hod new white tips. Although total dry weights of the two grosses were similor, the root/shoot ratio of fescue wos double thot of muhly (toble 1).

Pine seedling growth wos reloted to cover treotment. Pine seedlings grew best in boxes without gross (toble 2, figs. $4,5,6$ ). Both roots ond tops were oll significontly greoter for pines grown without grass than with gross. Pine growth wos slightly better in boxes contoining muhly thon those with fescue. 
Table 1.--Average growth per planter box of fescue and muhly grasses after two growing seasons

\begin{tabular}{l|r|c|c|c|c}
\hline \multirow{2}{*}{ Grass species } & \multicolumn{3}{|c|}{ Dry weight } & \multirow{2}{*}{$\begin{array}{c}\text { Root/shoot } \\
\text { ratio }\end{array}$} & Leaf height \\
\cline { 2 - 3 } & Roots & Tops & Total & & Inches \\
Fescue & $-\quad-\quad-$ Grams & - & & \\
Muhly & 106.0 & $249.3 a$ & $148.7 \mathrm{c}$ & $2.15 \mathrm{~d}$ & $10.3 \mathrm{f}$ \\
& 76.0 & $73.2 \mathrm{~b}$ & $149.2 \mathrm{c}$ & $1.04 \mathrm{e}$ & $14.3 \mathrm{~g}$ \\
\hline
\end{tabular}

${ }^{1}$ Root dry weight of the two grasses significantly different at the 10 percent level.

${ }^{2}$ Any two means in each column not followed by a similar letter are significantly different at the 5 percent level.

Table 2.--Average growth per plant of ponderosa pine seedlings grown in three cover types in planter boxes

\begin{tabular}{|c|c|c|c|c|c|}
\hline \multirow{2}{*}{ Cover type } & \multicolumn{3}{|c|}{ Dry weight } & \multicolumn{2}{|c|}{ Root growth } \\
\hline & Roots & Tops & Net gain 1 & $\begin{array}{c}\text { Active } \\
\text { laterals }\end{array}$ & $\begin{array}{c}\text { Longest } \\
\text { root }^{3} \\
\end{array}$ \\
\hline & - & - Grams & - & Number & Inches \\
\hline Fescue & ${ }^{4} 0.57 a$ & $0.90 c$ & $0.24 \mathrm{e}$ & $1.2 \mathrm{~g}$ & $20.8 i$ \\
\hline Muhly & $.96 a$ & $1.22 c$ & $.80 \mathrm{e}$ & $3.2 \mathrm{~g}$ & $22.8 \mathrm{ij}$ \\
\hline Grass-free & $3.37 b$ & $4.75 d$ & $6.76 f$ & $13.2 \mathrm{~h}$ & $27.5 j$ \\
\hline
\end{tabular}

${ }^{\text {INet }}$ gain $=$ dry weight (roots + tops) when harvested minus dry weight (estimated from green weight) when planted.

2 First- and second-order lateral roots with white tips were considered "active."

3 Measured from root crown to tip of longest lateral root.

${ }^{4}$ Any two means in each vertical column not followed by a similar letter are significantly different at the 5 percent level.

\section{Results of Field Tests}

Watered pine seedlings survived better than unwatered seedlings the first growing season. Mortality of watered pines averaged 32 percent, with no significant differences among the three cover types (fig. 7). Mortality of unwatered pines averaged about 72 percent, with significant differences among cover types.

Mortality of watered seedlings was highest during the first winter after planting, whereas mortality of unwatered seedlings was highest during the spring drought soon after planting.

Poor vigor of the pine seedlings was evident during the first growing seasnn. By July 14 , only 6 of the 36 excavated seedlings had new root growth. Furthermore, many of the pines had western gall rust.

Only 57 pines survived the two growing seasons. In general, unwatered pines in the denuded plots grew better than those in a grass cover (table 3). However, unwatered pines in muhly tended to grow better than those in fescue. Watered pines grew equally well in all cover types, but significantly less than those in unwatered bare plots.

Pine seedlings grew less than 2 inches in height during the two growing seasons. Watered fescue and muhly plants averaged 18 inches in height compared to 15 inches for unwatered. 
Roots, at enà of second growing season, washed from a glass-faced planter box:

\section{Figure 4.--}

Left, ponderosa pine and Arizona fescue;

Right, pine removed from fescue.

\section{Figure 5.--}

Left, ponderosa pine aria mountain muhly;

Fight, pine removed from muhly.
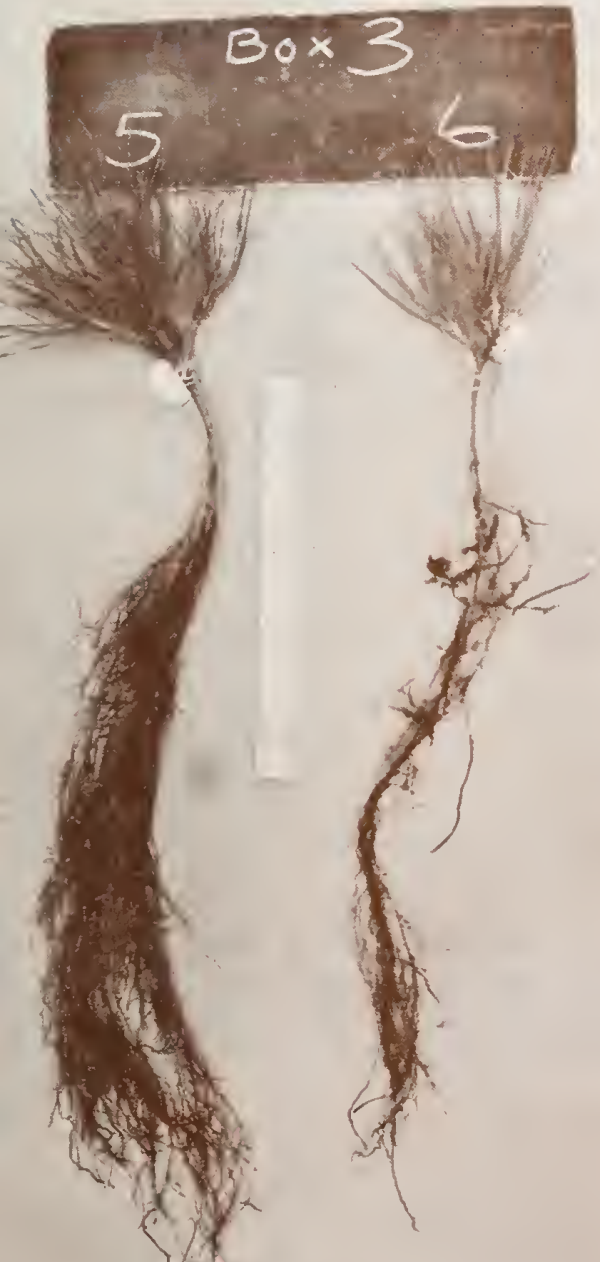

Figure 6.--Fonäerosa pine, grown without competing grass.
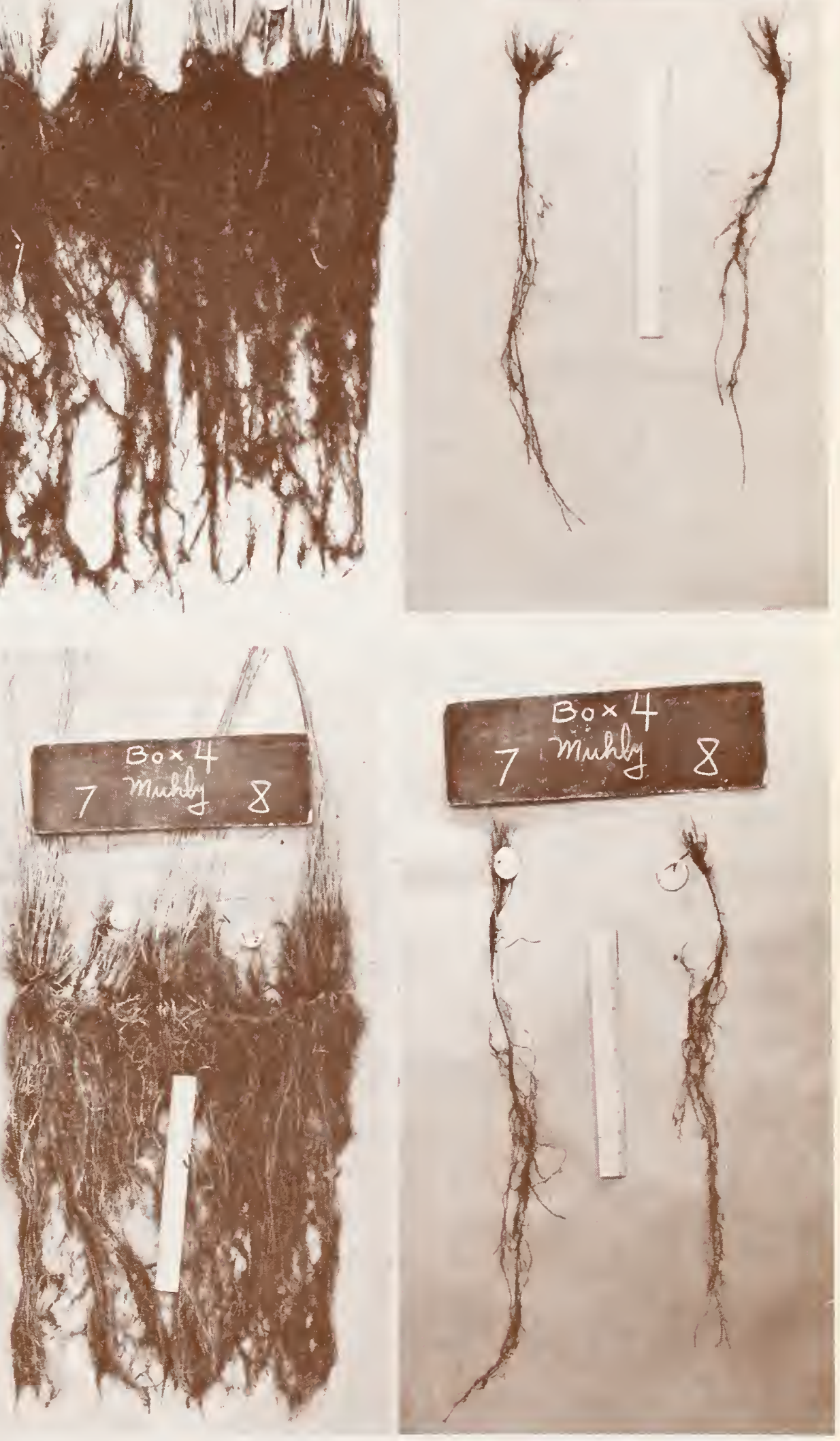


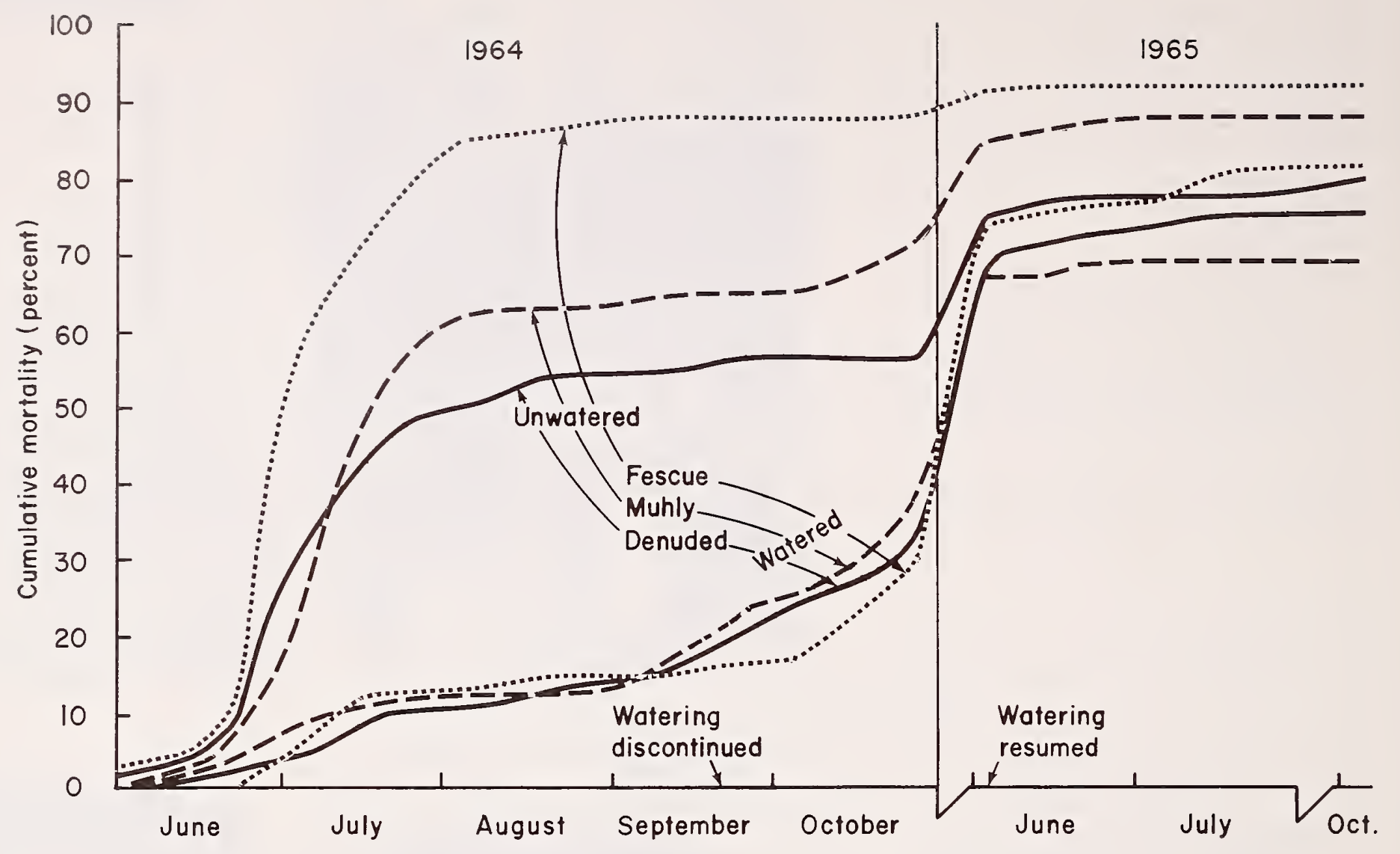

Figure 7.--Cumulative mortality of ponderosa pine seedlings planted in field plots containing Arizona f'escue and mountain muhly, 1964 (last count on October 27) and 1965 (Last count on October 4).

Table 3.--Average growth of unwatered ponderosa pine seedlings after two growing seasons, by cover type

\begin{tabular}{l|c|c|c|c|c}
\hline \multirow{2}{*}{ Cover type } & \multicolumn{2}{|c|}{ Dry weight } & \multicolumn{3}{c}{ Root growth } \\
\cline { 2 - 6 } & Roots & Tops & $\begin{array}{c}\text { Lateral } \\
\text { root } \\
\text { length }\end{array}$ & $\begin{array}{c}\text { Deepest } \\
\text { root }\end{array}$ & $\begin{array}{c}\text { Active } \\
\text { root } \\
\text { tips }\end{array}$ \\
\hline Fescue & $-\quad-$ Grams & - & $--\underline{\text { Inches }}--$ & $\underline{\text { Number }}$ \\
Muhly & $30.95 a$ & $1.10 a$ & $8.90 a$ & $18.45 a$ & $0.69 a$ \\
Denuded & $1.79 b$ & $2.76 a b$ & $10.70 a$ & $20.81 a$ & $2.19 a$ \\
\hline
\end{tabular}

IDetermined by averaging the four longest lateral roots of each seedling.

${ }^{2}$ All roots that had light-colored root tips were counted as "active." ${ }^{3}$ Any two means in each vertical column not followed by a similar letter are significantly different at the 5 percent level. 
Soil moisture depletion was least on the denuded and greatest on the fescue plots (figs. 8, 9). Soil moistures were significantly different in early July and October in 1964 and in July and September in 1965. Fescue reduced the moisture potential of soil at the 4 -inch depth to or below -15 bars twice during both years, whereas muhly reduced the moisture to this extent only once each year. Soil moisture below 16 inches was continuously adequate for plant growth both years. Soil moisture at the 4-inch depth in watered plots was maintained between 20 to 27 percent.

Thermistors installed in the moisture blocks performed too poorly to warrant a detailed presentation of the results. However, a few did provide consistent readings that indicated temperature trends. Soil temperatures at the 16- and 24-inch depths increased from the low $40^{\circ} \mathrm{F}$. in early May to about $70^{\circ}$ $F$. in mid-August. Noon soil temperatures at 4-inch depths exceeded $75^{\circ} \mathrm{F}$. only in the denuded unwatered plots. These temperatures averaged about $2^{\circ}$ to $4^{\circ} \mathrm{F}$. higher than those at the same depth in unwatered grass-covered plots and up to $16^{\circ}$ $F$. higher than those in watered denuded plots during the warm, dry periods. Soil temperatures in the watered grass plots averaged $3^{\circ}$ to $5^{\circ} \mathrm{F}$. cooler than those for unwatered plots. During the rainy season, soil temperatures at the 4 -inch depth were similar for all plots.

Average weekly air temperatures at 3 inches above the ground did not exceed $68^{\circ} \mathrm{F}$. during the two growing seasons
1964

30

20

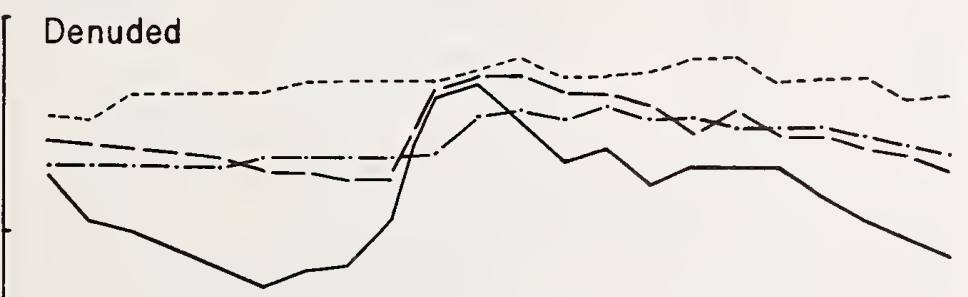

-15 bars

10

10

30

20

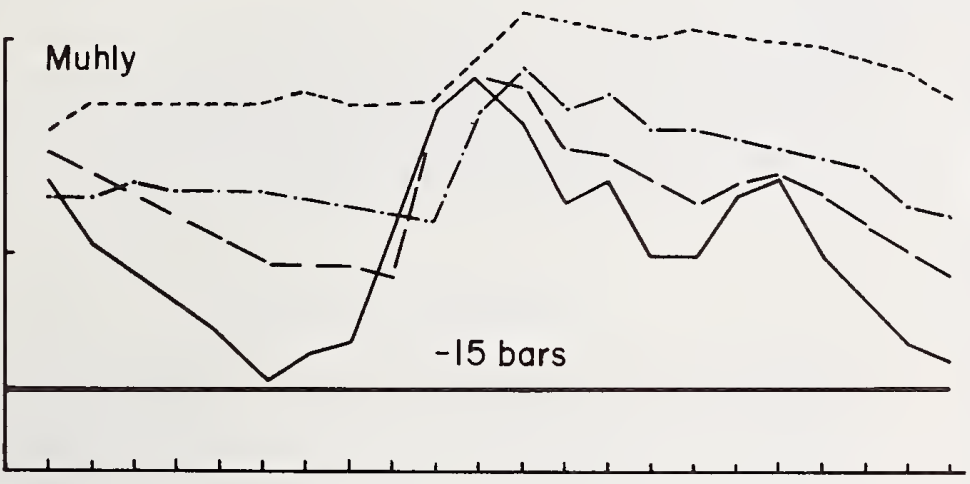

Soil depth (inches)

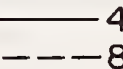

Denuded

1965

$-.-16$

$-\cdot---24$

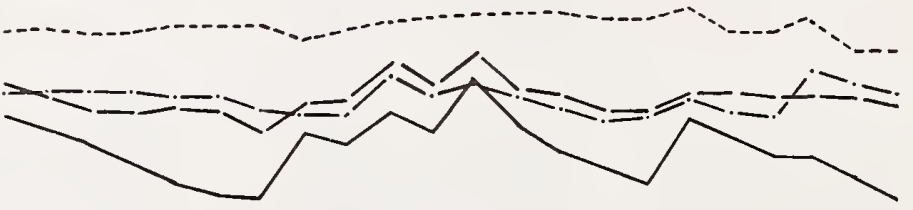

-15 bars

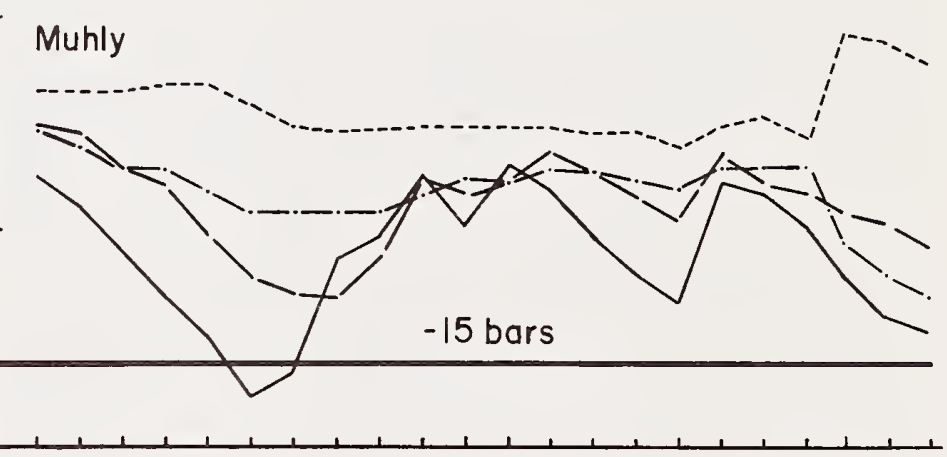

10

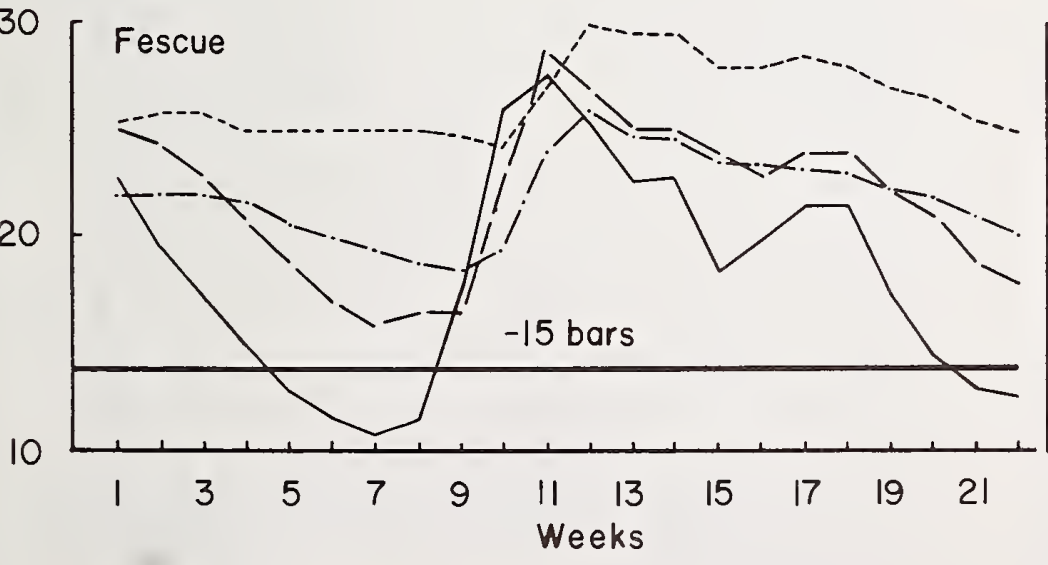

Figure 8.--1964.

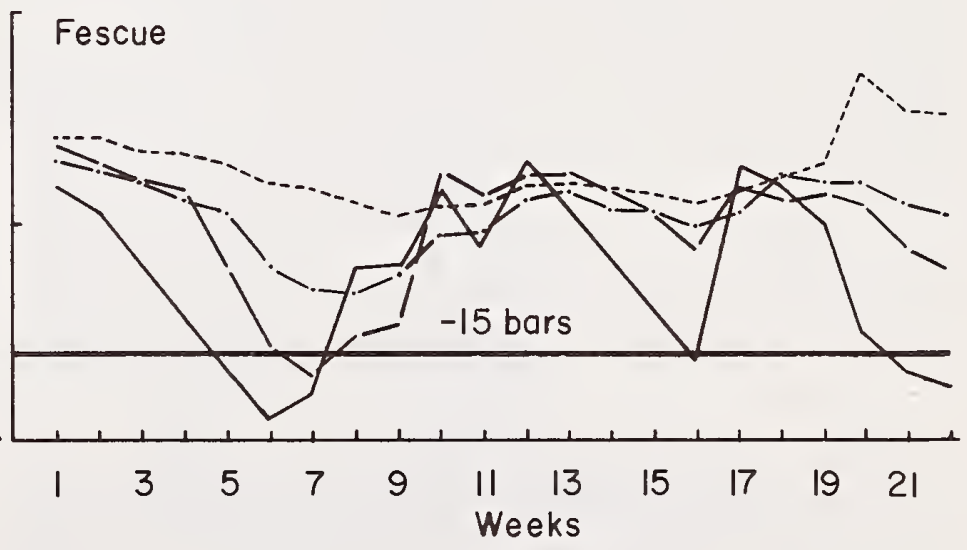

Figure 9.--1965.

Soil moisture (weight of water/weight of dry soil in percent) at indicated depths for each unwatered cover type June-October. Moisture content of surface soil at a matric potential of -15 bars is shown. 
(fig. 10). Average weekly minimum temperatures were usually under $50^{\circ} \mathrm{F}$. with temperatures dropping to or below $32^{\circ} \mathrm{F}$. every month. Maximum air temperatures never exceeded $100^{\circ} \mathrm{F}$.

About 11 inches of rain fell on the study area each year during the period June 1 to September 30. Relative humidities ranged from 15 to 30 percent at noon during the drought periods, and 40 to 50 percent during the late July-August wet periods.

Needle moisture content (NMC) of the pines averaged 165 percent at time of planting. On June 3 , the average NMC of the needles dropped to 140 percent, with no significant treatment differences (table 4). By July 11, near the end of the spring drought, the NMC of live seedlings averaged only 108 percent. At this time the average NMC of watered seedlings was significantly higher than that of unwatered seedlings in each cover type. Furthermore, the NMC of unwatered seedlings was significantly higher for pines in the denuded plots than in the two grass-covered plots. By August 31 (after several rains) the average NMC of live seedlings was up to 128 percent.

Trends in water saturation deficits (WSD) of seedlings were similar to those of NMC (table 4). Values for WSD and NMC are inversely related to each other. The WSD was 8 percent (near full saturation) at time of planting, 35 percent on July 11 (symptoms of wilting observed) and 28 percent on August 31. Both WSD and NMC were more favorable for survival of unwatered pines than of watered pines on August 31 . The water balance of needles (WSD and NMC) was similar for the two collection times - just before sunrise and 10 hours after sunrise.

The NMC and WSD measurements on June 3 were related to the seedlings' ability to survive the ensuing drought period

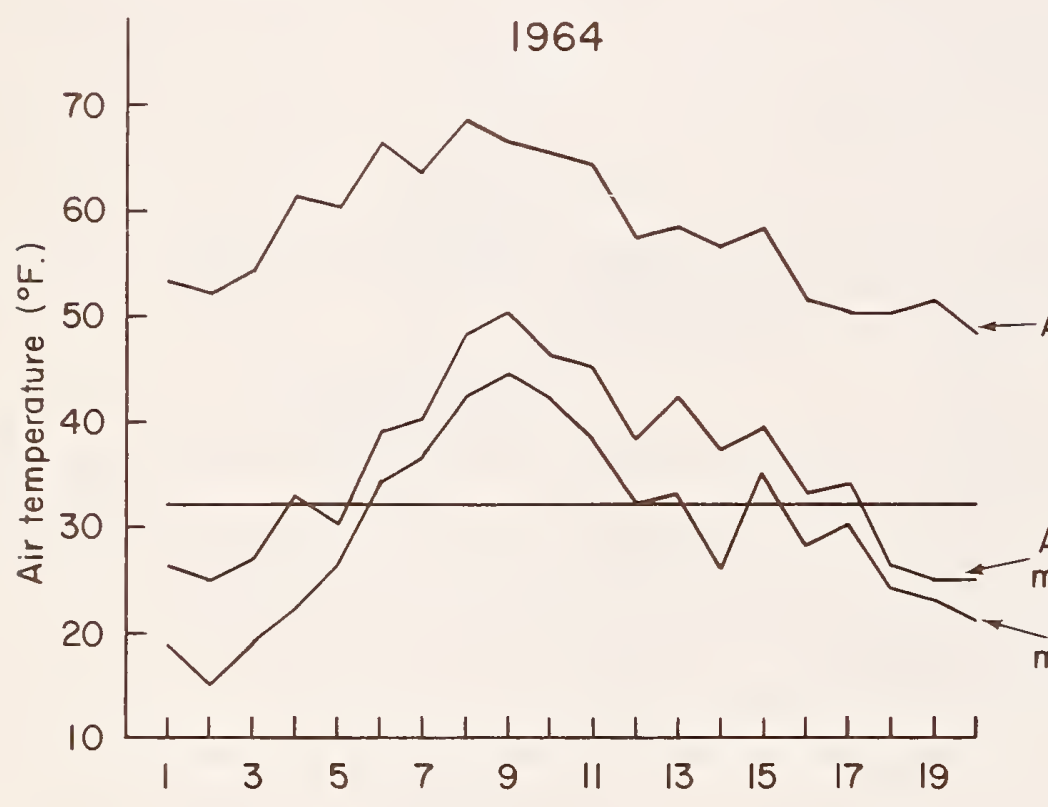

1965
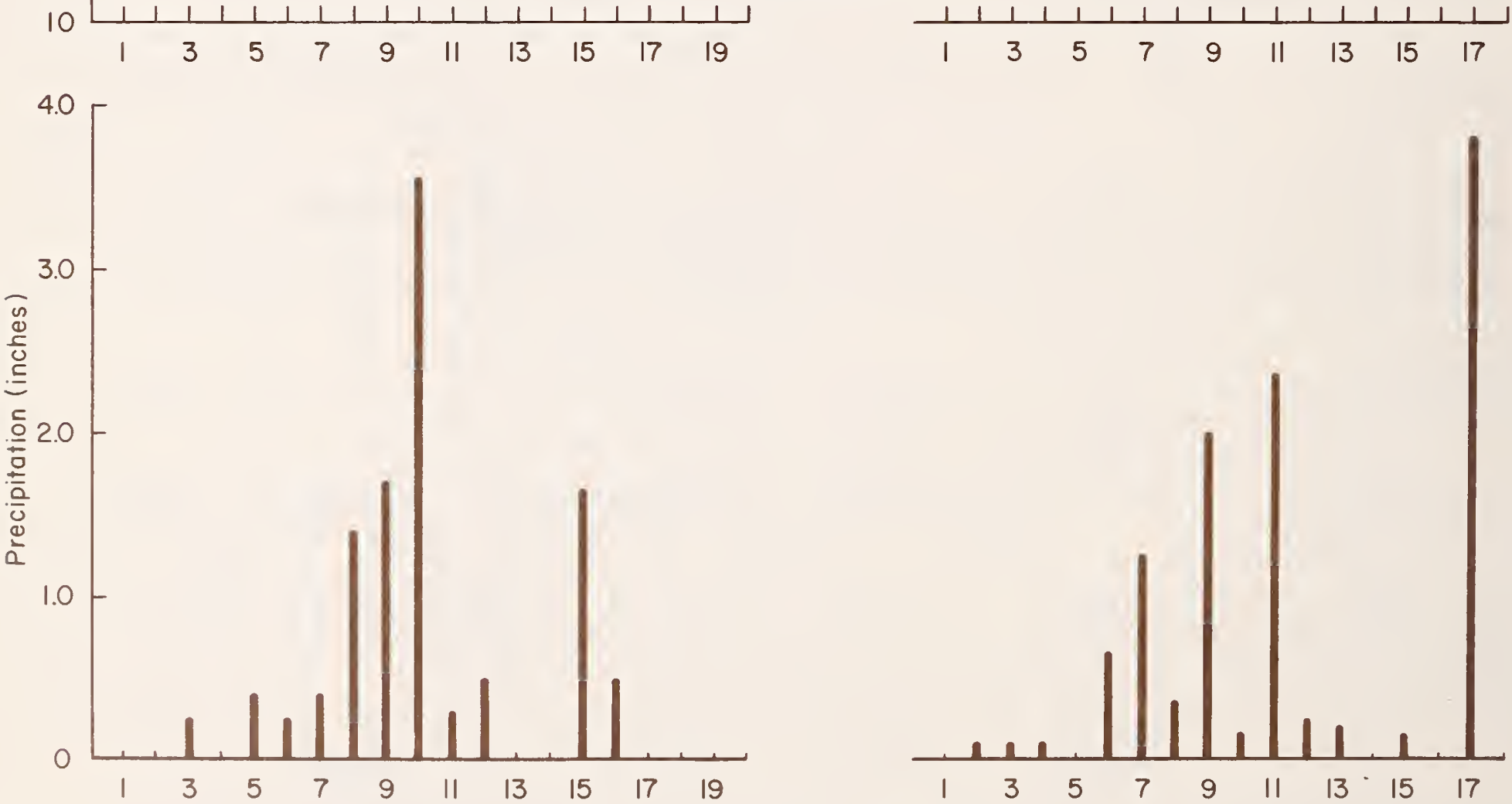

Number of weeks

Figure 10.--Air temperatures at 3 inches above ground level (weekly average, weekly average minimum, and lowest minimum recorded each week) and total weekly precipitation during two growing seasons 1964 (June-October) and 1965 (June-September). 
Table 4.--Averages of needle moisture content (NMC) and water saturation deficit (WSD) of ponderosa pine seedlings at three dates during the first growing season after planting. (Needles collected 10 hours after sunrise on clear days)

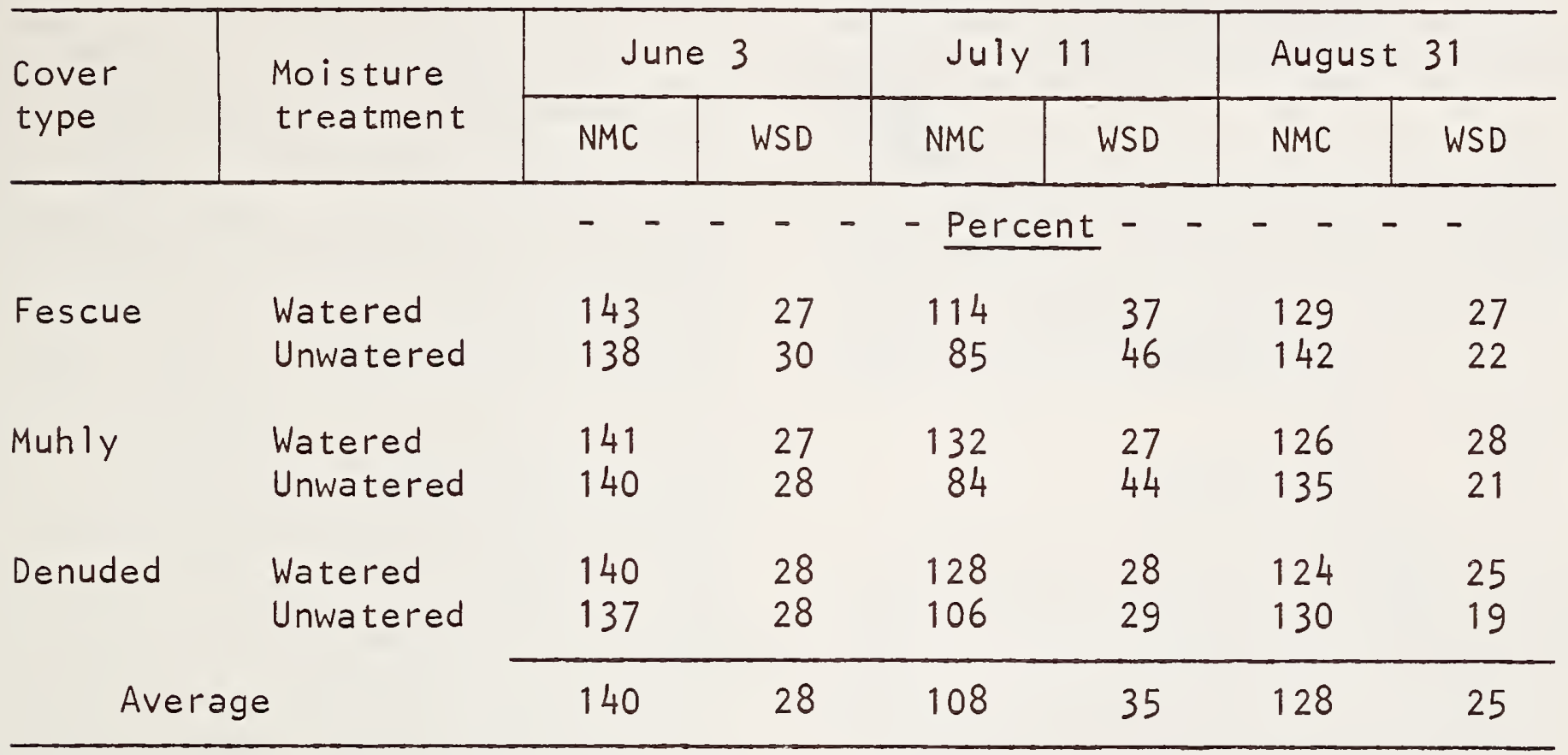

(figs. 11, 12). The probobility of survivol of wotered seedlings remoined favoroble $(0.70)$ even when the June 3 NMC wos low ( 110 percent) or the WSD wos high (50 percent). In controst, the probobility of survivol of unwotered pine seedlings wos less thon 50 percent when the NMC was below 146 percent or the WSD wos obove 25 percent.

\section{Discussion and Conclusions}

The investigotion of the noture ond effect of competition between ponderoso pine seedlings ond gross hos provided doto on growth comparisons ond reosons why pines survive ond grow better in gross-free environments.

Ponderoso pine seedlings grew best on well-prepored plots. Root ond top growth were both significontly greoter when pines were grown without competition from gross. The pine seedlings on denuded plots showed on elevenfold greoter net goin in dry weight thon those grown in competition with gross. Dry weights of roots ond tops of pines grown on bore soil were over four times more thon for pines grown in gross.

Mountoin muhly, o worm-seoson grower, retorded growth of ponderoso pine seedlings less thon did Arizono fescue, a coolseoson grower. Net goin in dry weight of pines growing with muhly wos neorly four times thot of pines growing with fescue.

Gross roots grew foster thon pine roots. Moin roots of muhly ond fescue elongoted ot o rote 50 percent greoter ond thereby occupied o given volume of soil sooner thon pine roots. At the end of 2 yeors, dry weight of gross roots wos 11 to 16 times greoter thon the weight of the tree roots for seedlings grown in plonier boxes. However, the root weight of the grosses in the boxes wos three to four times greater thon the root weights reported for o similor volume of soil in on ungrozed mountoin muhly posture in Colorodo (Schuster 1964).

Arizono fescue ond mountoin muhly were more drought toleront than ponderosa pine seedlings. Gross, in the field plots, recovered originol greenness ond grew vigorously following the lote spring-eorly summer drought when the soil moisture wos replenished by July ond August roins. In controst, obout holf of the newly plonted pines in the field plots died during the drought period unless wotered. Roots of both pine ond grosses become dormont os the soil dried out in the plonter boxes. When the soil wos rewetted ond kept moist, the grasses produced mony new laterals ond o flush of new moin roots within 2 to 3 weeks, whereos pines produced only a few new roots ofter rewetting.

A faster recovery of brome grass over hordwood seedlings during droughts wos olso reported by Lone and McComb (1948). Richordson (1953) observed that grosses reduced the period of octive root growth of Acer seedlings, ond noted thot gross suppressed loterol root growth more thon the moin root of tree seedlings. In our study, loterols grew more on pine seedlings grown without gross thon in boxes with gross.

Arizono fescue ond mountoin muhly depleted soil moisture foster ond to lower levels than ponderoso pines. Similor results were reported by Peorson (1950) in soil moisture trends in noturol gross and denuded oreos. Arizono fescue depleted the soil moisture more thon mountoin muhly, ond reduced it to criticol levels for plont growth during both the spring and foll droughts. Conord ond Youngmon (1965) found thot cold-seoson postures suffered more often from midsummer drought thon worm-seoson postures. Borrett ond Youngberg (1965) reported - 45 percent greoter use of woter in o sopling stond of ponderoso pine with an understory thon in one without on understory.

Arizono fescue completed its height growth by obout midJune compored to lote summer for mountoin muhly. Jomeson (1965) found similor times for finol height growth of other worm- ond cold-seoson grosses in northern Arizono. In our study both grosses formed new short leoves in the foll thot were corried through the winter.

Pine seedlings hod o loterol root system odvontoge over the grosses. Some first-yeor loterols on the pines exceeded 30 inches in the field experiments. Schuster (1964) reported thot the root spreod for fescue ond muhly overoged only obout 1 foot in ungrozed postures. This widespread root system of pines 

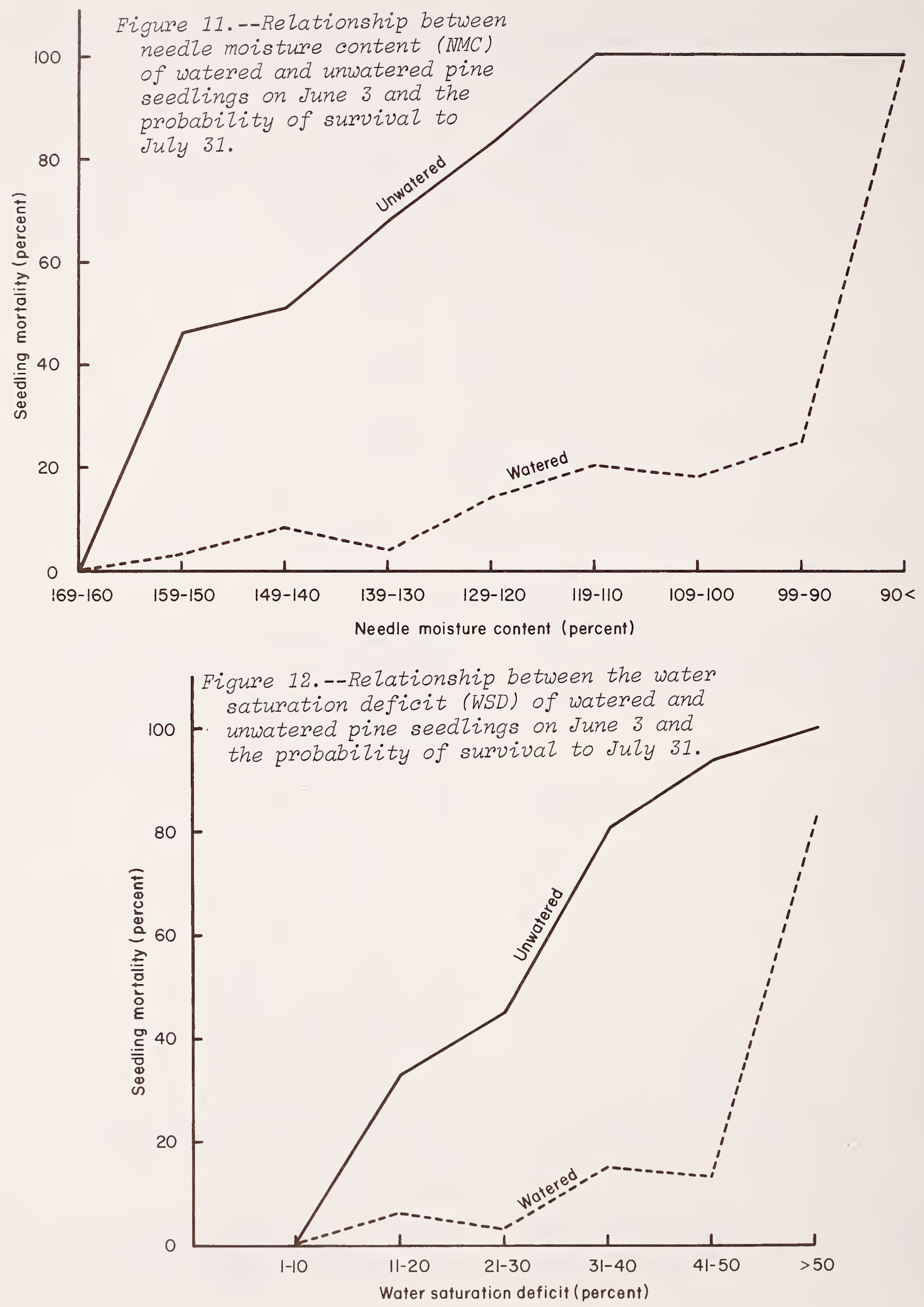
is better than the compact root system of grasses because it provides a larger area to tap soil moisture.

Soil moisture remained high below the 16-inch depth for all cover types, with few grass roots below this depth. Similar results were obtained by Schuster (1964) and by Cohen and Strickling (1968). Main roots of all surviving pines extended below the 16 inch depth.

Established pines can tolerate some competition for moisture by grasses. Only 9 percent of the pines that survived the first drought period died during the second growing season. In California, Baron (1962) found that ponderosa pines were able to compete with grasses if the pines were planted before or at the same time the area was seeded with grass. However, pines sustained heavy mortality on areas planted a year or more after the grass seeding. In Arizona, pines from the successful 1919 seedling crop gained dominance over the grasses within 5 years (Arnold 1950). Pearson (1942) reported that pines from the 1919 seedling crop survived in great numbers in competition with muhly but not with fescue.

Pine seedlings grew best in unwatered bare plots. The relatively poor growth of watered seedlings may have been due to excessive water at the lower soil depths. Soil moisture at the 4 -inch depth usually remained below field capacity, but mois ture at lower depths was not measured in watered plots. Also, the midday soil temperatures of unwatered plots were often considerably higher and more favorable for seedling growth than were the temperatures of watered plots.

There was no evidence that grass roots produced growth inhibitors that suppressed the elongation of pine roots. Pine roots elongated as rapidly in boxes with grass as those without grass as long as soil moisture was adequate (fig. 2). Also, pine seedling survival the first season in the watered field plots was similar for all cover types. The grasses may have produced growth inhibitors when soil moisture stress was high, but the two effects cannot be separated in these data.

Height growth of pine seedlings was a poor indicator of competition. Frequently, ponderosa pines make very little top growth the first year or two after outplanting. Most of the growth during these years is on the root system. Richardson (1953) concluded that height increment was an unsatisfactory basis for comparative growth studies of young trees. Sutton (1967) found that first-year height increment of outplanted spruce seedlings was similar for several levels of root pruning.

Water balance of pine seedlings varied both with season and treatment. The needle moisture content (NMC) and water saturation deficits (WSD) data indicated that the internal moisture stress of needles was low at time of planting and very high during early summer drought. During this drought period, pine seedlings in unwatered plots containing fescue and muhly developed greater internal moisture stresses than pines in denuded or watered plots. After 2 months of summer rains, however, the water balance of unwatered pines was better than that of the watered pines (table 4). This late summer difference in water balance may not be significant, however. The NMC and WSD data recorded on August 31 included statistics for poorquality watered pines that later died during the fall and winter months (fig. 7). The poor-quality unwatered pines were not included since they had already died during the June drought.

Water saturation deficit (WSD) of pine seedlings on June 3 was a better indicator of survival potential than NMC (figs. 11, 12). Seedlings with WSD values above 25 percent on June 3 had less than a 50-50 chance to survive the June drought. Oppenheimer and Shomer-llan (1963) observed internal cellular damage in needles of Pinus pinea and $P$. halepensis that reached a WSD of 25 percent.

Pine needles displayed various visual symptoms of drought damage. These symptoms were related to NMC as follows: needles green, 150 percent; needles light green, 111 percent; tips of needles brown, 107 percent; needles with purplish cast,
101 percent; needles with necrotic yellow spots, 84 percent; and needles yellow, 55 percent. The coefficients of variation ranged from 5 percent for seedlings with yellow needles to 17 percent for seedlings with light green needles. A needle moisture content (NMC) (based on ovendry weight) less than 110 percent combined with a WSD greater than 45 percent appears to be the "point of no return" for ponderosa pine seedling survival. Ursic (1961) concluded that an NMC of about 80 percent identified the death point of loblolly pine (Pinus taeda L.) seedlings.

Needles subjected to severe drought may not fully recover their former turgidity after the drought is broken. Freshly cut needle fascicles were saturated and subjected to simulated drought conditions by drying until various water saturation deficits (WSD) up to 42.2 percent were reached. The needles were then resaturated and reweighed. Differences in water content between first and second saturations became progressively larger as the WSD increased.

\section{Recommendations}

Results of this study show that ponderosa pine should be planted only on grass-free areas. Therefore, if grass is present, it must be killed or removed before trees are planted. Furthermore, since water is in short supply and pine roots reach out several feet, complete site preparation provides the best condition for tree survival and growth. Partial site preparation has been inadequate and is not recommended for the Southwest.

Grass can be effectively killed with dalapon during the summer or removed with a bulldozer in the fall before planting. Current research will determine if grass can be effectively killed with other herbicides at time of planting. Until new research provides other alternatives, dalapon or bulldozer treatment at the recommended times are the best methods to prepare planting areas.

\section{Liferofure Ciłed}

Arnold, J. F.

1950. Changes in ponderosa pine bunchgrass ranges in northern Arizona resulting from pine regeneration and grazing. J. Forest. 48: 118-126.

Baron, F. J.

1962. Effects of different grasses on ponderosa pine seedling establishment.*. USDA Forest Serv., Pacific Southwest Forest and Range Exp. Sta. Res. Note 199, 8 pp. Berkeley, Calif.

Barrett, J. W., and Youngberg, C. T.

1965. Effect of tree spacing and understory vegetation on water use in a pumice soil. Soil Sci. Soc. Amer. Proc. 29: $472-475$

Cohen, O.P., and Strickling, E.

1968. Moisture use by selected forage crops. Agron. J. 60: $587-590$.

Conard, E. C., and Youngman, V.E.

1965. Soil moisture conditions under pastures of cool-season and warm-season grasses. J. Range Manage. 18: 74-78.

Harms, W. R., and MCGregor, W. H. D.

1962. A method of measuring the water balance of pine needles. Ecology 43: 531-532.

Jameson, D. A.

1965. Phenology of grasses of the northern Arizona pinyon-juniper type." U.S. Forest Serv. Res. Note RM-47, 8 pp. Rocky Mountain Forest and Range Exp. Sta., Fort Collins, Colo. 
Lane, R. D., ond McComb, A. L.

1948. Wilting and soil moisture by tree seedlings and gross. J. Forest. 46: 344-349.

Larson, M. M.

1962. Construction ond use of glass-foced boxes to study root development of tree seedlings." USDA Forest Serv., Rocky Mountain Forest and Ronge Exp. Sta. Res. Note Lavin, $F$. 73, 4 pp. Fort Collins, Colo.

1961. A gloss foced planter box for field observotion on roots. Agron. J. 53: 265-268.

Oppenheimer, H. R., and Shomer-llon, A.

1963. [A contribution to the knowledge of drought resistonce of Mediterronean pine trees] Mitteilungen der Floristisch-soziologischen Arbeitsgemeinschaft N.F. 10: 4255.

Pearson, G. A

1942. Herbaceous vegetotion as o factor in the noturol regeneration of ponderoso pine in the Southwest. Ecol. Monogr. 12: 315-338.
1950. Monagement of ponderoso pine in the Southwest. U.S. Dep. Agr. Agr. Monogr. 6, 218 pp.

Richardson, S. D.

1953. [Root growth of Acer pseudoplatanus L. in relotion to gross cover and nitrogen deficiency. Mededelingen von de Londbouwhogeschool te Wogenningen/ Nederlond 53: 75-97.

Schuster, J. L.

1964. Root development of native plants under three grozing intensities. Ecology 45: 63-70.

Sutton, R. F.

1967. Influence of root pruning on height increment ond root development of outplanted spruce. Con. J. Bot. 45: 1671-1672

Ursic, S. J.

1961. Tolerance of loblolly pine seedlings to soil moisture stress. Ecology 42: 823-825

*Address requests for copies to the originoting office.

\section{USE PESTICIDES CAREFULLY!}

This publication reports research involving pesticides. It does not contain recommendations for their use, nor does it imply that the uses discussed here have been registered. All uses of pesticides must be registered by appropriate State and/or Federal agencies before they can be recommended.

Pesticides can be injurious to humans, domestic animals, desirable plants, honeybees and other pollinating insects, and fish or other wildlife--if they are not handled or applied properly. Use all pesticides selectively and carefully. Follow recommended practices for the disposal of surplus pesticides and their containers. 

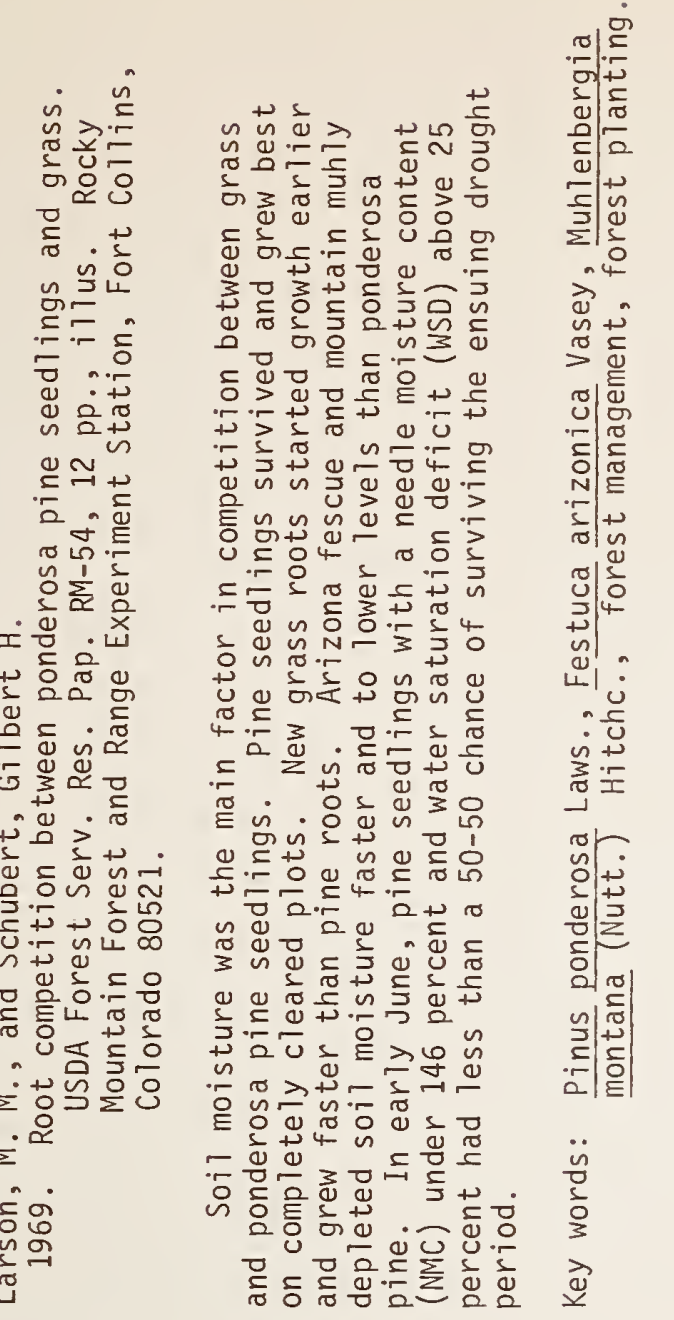

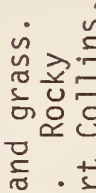

ขั

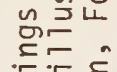

$\therefore$ 등

峛茎恋

$\approx \simeq$

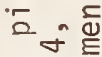

ช0

$x$

등ㅎㅁㅇ

可语

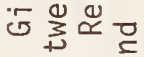

+⿱艹

这垴苍芯

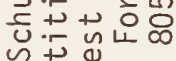

든단듀

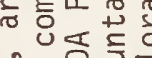

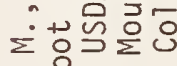

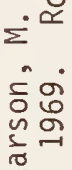

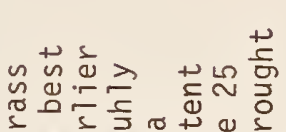

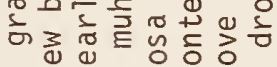

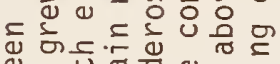

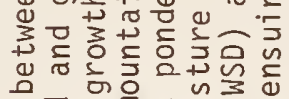

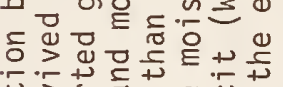

更

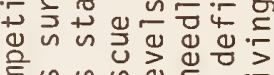

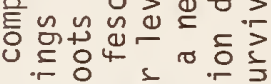

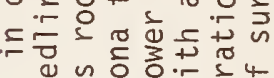

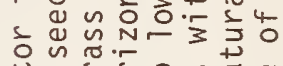

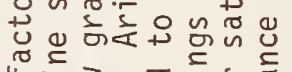

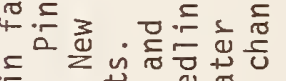

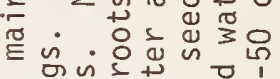

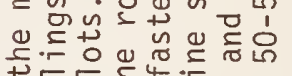

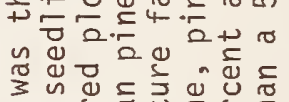

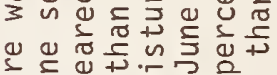

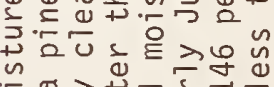

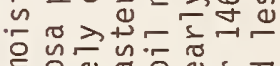

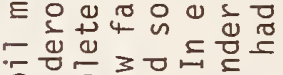

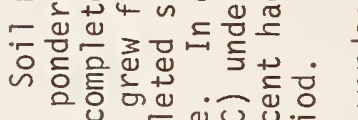

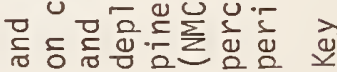

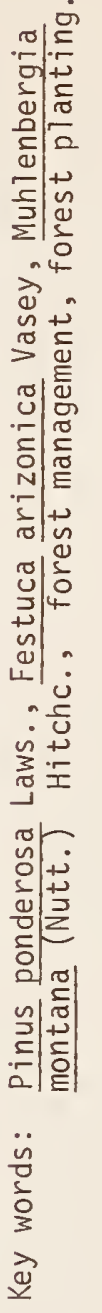




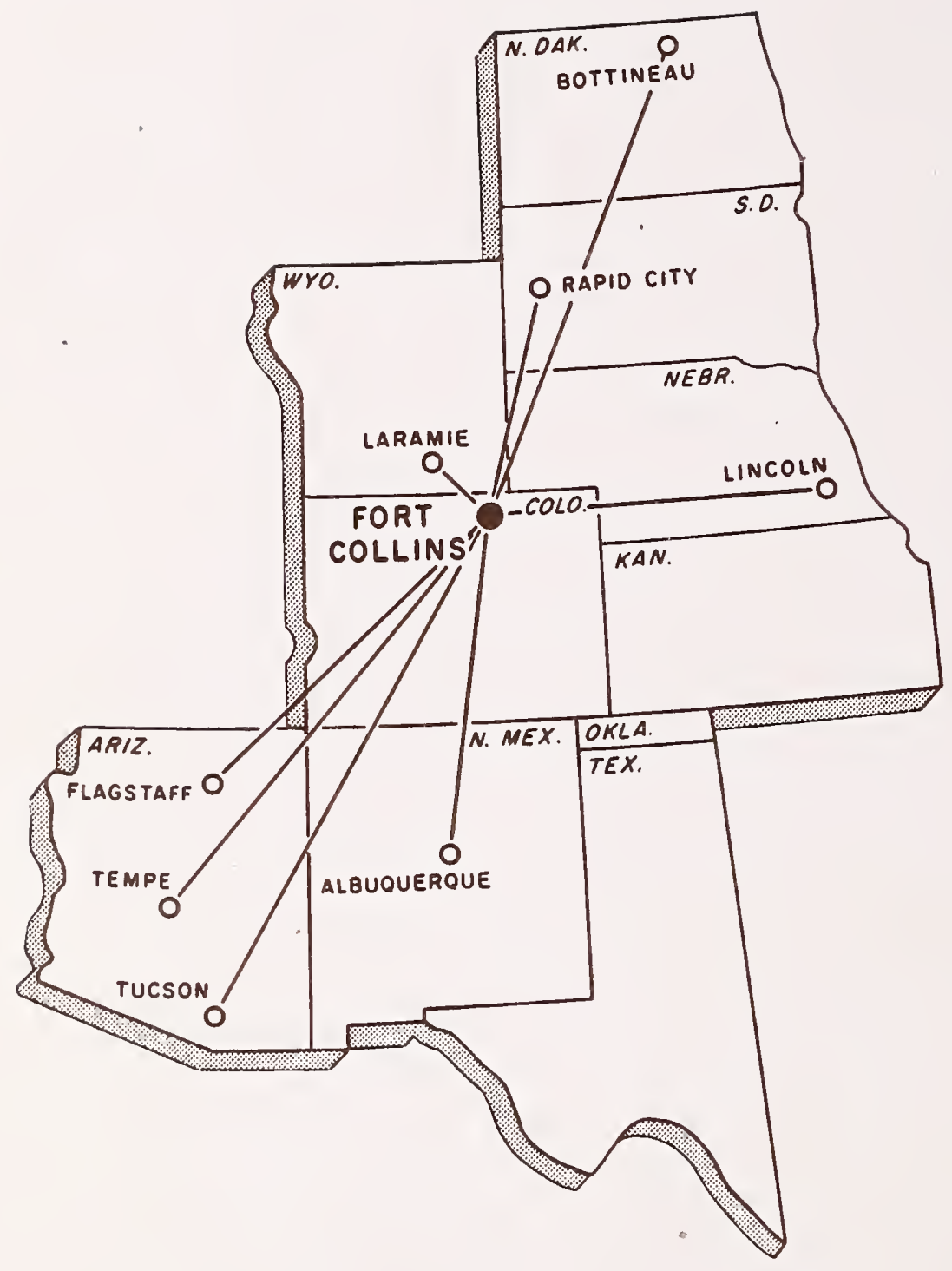

